\title{
Expression Analysis of OIP5-AS1 in Non-Small Cell Lung Cancer
}

\section{Expresní analýza OIP5-AS1 u nemalobuněčného karcinomu plic}

\author{
Esfandi F. ${ }^{1,2}$, Kholghi Oskooei V. ${ }^{1}$, Taheri F. ${ }^{2}$, Kiani A ${ }^{3}$, Taheri M. ${ }^{1,4}$, Ghafouri-Fard S. ${ }^{1}$ \\ 'Department of Medical Genetics, Shahid Beheshti University of Medical Sciences, Tehran, Iran \\ ${ }^{2}$ Genlran Lab, Tashkhis Gene Pajohesh, Tehran, Iran \\ ${ }^{3}$ Tracheal Diseases Research Center, National Research Institute of Tuberculosis and Lung Diseases (NRITLD), Shahid Beheshti University of Medical \\ Sciences, Tehran, Iran \\ ${ }^{4}$ Urogenital Stem Cell Research Center, Shahid Beheshti University of Medical Sciences, Tehran, Iran
}

\begin{abstract}
Summary
Background: Lung cancer as the most fatal cancer of men has prompted researchers to find biomarkers for early detection and prognosis. Among the possible biomarkers are a group of non-coding transcripts with sizes more than 200 nucleotides called long non-coding RNAs (IncRNAs). Aims: In the present study, we evaluated the expression levels of the IncRNA OIP5 antisense RNA 1 (OIP5-AS1) in 32 non-small cell lung cancer (NSCLC) samples compared with their corresponding adjacent non-cancerous tissue (ANCTs) by means of real-time polymerase chain reaction. The samples were obtained from patients who were admitted at Labbafi-Nejad Hospital during 2015 and 2016. Results: OIP5-AS expression levels was significantly decreased in tumoral tissues compared with ANCTs in total samples and in male subgroup. However, no association was found between relative expression of OIP5-AS1 and clinicopathological data of patients or history of smoking. Expression levels of this IncRNA were not correlated with patients' age. Conclusions: This IncRNA is possibly a novel biomarker of NSCLC in Iranian patients. Future studies are needed to confirm the results of our study in larger sample sizes. Moreover, based on the difference in lung cancer associated risk factors in different populations, population-based studies are needed to explore the role of this IncRNA in the pathogenesis of cancers in each region to design appropriate targeted therapies for each population.
\end{abstract}

\section{Key words}

lung cancer - OIP5-AS - IncRNA - long non-coding RNA

\section{Souhrn}

Úvod: Karcinom plic jako nejvíce fatální nádor mužů přiměl výzkumníky ke hledání biomarkerů pro včasnou detekci a prognózu. Mezi možné biomarkery patří skupina nekódujících transkriptů o velikosti více než 200 nukleotidů nazývaná dlouhé nekódující RNA (IncRNA). Cíle: $V$ této studii jsme vyhodnotili hladiny exprese OIP5 antisense RNA 1 (OIP5-AS1) u 32 vzorků nemalobuněčného karcinomu plic (non-small cell lung cancer - NSCLC) ve srovnání s odpovídající sousedící nenádorovou tkání (adjacent non-cancerous tissue - ANCT) pomocí polymerázové řetězové reakce $v$ reálném čase. Vzorky byly získány od pacientů, kteří byli přijati v nemocnici Labbafi-Nejad v letech 2015 a 2016. Výsledky: Úrovně exprese OIP5-AS byly významně sníženy v nádorových tkáních ve srovnání s ANCT v celkových vzorcích a v podskupině mužů. Nebyla však zjištěna žádná souvislost mezi relativní expresí OIP5-AS1 a klinicko-patologickými daty pacientů nebo historií kouření. Expresní hladiny této IncRNA nebyly korelovány s věkem pacientů. Závěry: Tato IncRNA je možný nový biomarker NSCLC u iránských pacientů. K potvrzení výsledků naší studie jsou potřebné budoucí studie u větších počtů pacientů. Navíc na základě rozdílu v rizikových faktorech spojených s rakovinou plic v různých populacích jsou studie založené na populaci potřebné k prozkoumání role této IncRNA v patogenezi onkologických onemocnění v každé oblasti za účelem navržení vhodných cílených terapií pro každou populaci.

\section{Klíčová slova}

karcinom plic - OIP5-AS - IncRNA - dlouhé nekódující RNA
The current study was supported by a grant from Shahid Beheshti University of Medical Sciences (grant number: 12810).

Studie byla podpořena grantem Univerzity lékařských věd Shahid Beheshti (č. 12810).

The authors declare they have no potential conflicts of interest concerning drugs, products, or services used in the study.

Autoři deklaruji, že $v$ souvislosti $s$ predmětem studie nemaji žádné komerční zájmy.

The Editorial Board declares that the manuscript met the ICMJE recommendation for biomedical papers.

Redakční rada potvrzuje, že rukopis práce splnil ICMJE kritéria pro publikace zasilané do biomedicínských časopisů.

$\equiv$

Soudeh Ghafouri-Fard, MD, PhD

Department of Medical Genetics Shahid Beheshti University of Medical Sciences

Bldg No.2 SBUMS

Arabi Ave, Daneshjoo Blvd, Velenjak Tehran, Iran

e-mail: s.ghafourifard@sbmu.ac.ir

Mohammad Taheri, MD

Genlran Lab

Tashkhis Gene Pajohesh

89 Mofateh Street, no.2

Tehran, Iran

e-mail:mohammad_823@yahoo.com

Submitted/Obdrženo: 25. 4. 2018

Accepted/Přijato: 27. 5. 2018

doi: $10.14735 / a m k o 2018260$ 


\section{Background}

Lung cancer has been regarded as the most fatal cancer in men and women worldwide and in distinct regions, resp. [1]. Analysis of data provided by the Iranian National Pathology Based Cancer Registry (INPBCR) estimated the 5-year prevalence to be 4.21 (95\% uncertainty level - 3.37-5.38) per 100,000 adults, with a male - female ratio of 2.01 [2]. The most common type of lung cancer is non-small cell lung cancer (NSCLC) which accounts for approximately $85 \%$ of all cases and is further categorized into three types - squamous-cell carcinoma, adenocarcinoma, and large-cell carcinoma [3]. The cure rate of patients is disappointedly low [4] possibly due to extensive disease burden, unsuitable performance condition, several comorbidities, deprived socio-economic status and malnutrition [5]. Identification of proper biomarkers for early detection of lung cancer is expected to enhance patients' outcomes. Among putative biomarkers for lung cancer are long non-coding RNAs (IncRNAs). These heterogeneous types of transcripts have various fundamental functions in gene regulation and are involved in the pathogenesis of human cancers [6-11]. A comprehensive study to find the IncRNA and mRNA signature in lung adenocarcinoma samples and normal tissues has identified more than two thousands IncRNAs with differential expression in these two sets of samples [12]. More recently, the IncRNA opa interacting protein 5 -antisense 1
(OIP5-AS1) has been shown to be involved in the pathogenesis of lung adenocarcinoma through sponging miR-448 and indirectly altering the expression of $\mathrm{BCl}-2$ [13]. The present study aimed to assess the expression level of OIP5-AS1 in NSCLC samples compared with their corresponding adjacent non-cancerous tissues (ANCTs). We hypothesized that the expression level of this IncRNA is higher in cancerous tissues compared with ANCTs in association with patients' clinical data.

\section{Methods}

Patients' samples

A total of 32 patients with definite diagnosis of NSCLC who were admitted at Labbafi-Nejad Hospital during 2015 and 2016 entered the study. Lung cancer tissues and the corresponding ANCTs were removed during surgery and snapfrozen in liquid nitrogen instantly. All patients signed the informed consent forms. The study protocol was approved by the ethics committee of Shahid Beheshti University of Medical Sciences (IR.SBMU.MSP.REC.1395.525).

\section{Sampling and \\ RNA extraction}

Total RNA was isolated from cancerous tissues and ANCTs using the TRIzol ${ }^{\mathrm{TM}}$ Reagent (Invitrogen, Carlsbad, CA, USA) based on the protocol provided by the company except for inclusion of a DNase I treatment step. RNA concentration was assessed by $260 / 280 \mathrm{nM}$ absorbance

Tab. 1. The primers and probes sequences and PCR product length.

\begin{tabular}{l|c|c|c|}
\hline $\begin{array}{l}\text { Gene } \\
\text { name }\end{array}$ & Primer and probe sequence & $\begin{array}{c}\text { Primer } \\
\text { and probe } \\
\text { length }\end{array}$ & $\begin{array}{c}\text { Product } \\
\text { length }\end{array}$ \\
\hline HPRT1 & F: AGCCTAAGATGAGAGTTC & 18 & \\
& R: CACAGAACTAGAACATTGATA & 21 & 88 \\
\hline & FAM -CATCTGGAGTCCTATTGACATCGC-TAMRA & 24 & \\
\hline & F: TCAGCCTCCCAAGTAGCTAGG & 20 & \\
\hline & R: GTCCCAGCCTTTTCAGCCTAG & 21 & 77 \\
\hline & FAM- CGCACCACCACGCTCAGCCTGATT-TAMRA & 24 & \\
\hline
\end{tabular}

using Nanodrop equipment (Thermo Scientific).

\section{cDNA synthesis and quantitative} real-time polymerase chain reaction (RT-PCR)

Applied Biosystems High-Capacity cDNA Reverse Transcription Kits was used for cDNA synthesis based on the manufacturer's instructions. Afterwards, synthesized cDNAs were stocked at $-20{ }^{\circ} \mathrm{C}$ until PCR was performed. Primers and probes used for PCR were designed using the allele ID 7 for $x 64$ Windows software (Premier Biosoft, Palo Alto, USA). HPRT1 was chosen as the reference gene. The primers and probes sequences and PCR product length are shown in Tab. 1. All experiments were performed on the rotor gene 6000 corbett RT-PCR System. Applied Biosystems TaqMan ${ }^{\circ}$ Universal PCR Master Mix was used for quantification of relative levels of transcripts. PCR program included a denaturation step at $95{ }^{\circ} \mathrm{C}$ for $10 \mathrm{~min}$, followed by 40 cycles of $95^{\circ} \mathrm{C}$ for $10 \mathrm{sec}$ and $60^{\circ} \mathrm{C}$ for $60 \mathrm{sec}$. The final extension step was performed at $72{ }^{\circ} \mathrm{C}$ for $5 \mathrm{~min}$.

\section{Statistical analysis}

SPSS version 18 (Chicago, IL, USA) was used for statistical analysis. Relative expression of OIP5-AS1 in tumoral tissues compared with ANCTs was assessed using $\mathrm{Ln}$ [Efficiency^$\triangle \mathrm{CT}$ ] values. The association between OIP5-AS1 relative expressions and clinicopathologic data of patients was estimated using Chi-square test. Spearman correlation coefficient was calculated to assess the correlation between OIP5-AS1 transcript levels and patient's age. To test the significance of difference in means of transcript levels between tumor and ANCT groups we used Kruschke's Bayesian estimation to fit two-sample Bayesian paired t-test. $P$ values less than 0.05 were considered significant.

\section{Results}

Relative expression of OIP5-AS in lung cancer tissues compared with ANCTs OIP5-AS1 expression levels were significantly decreased in tumor tissues compared with ANCTs in total samples and in male subgroup (Tab. 2). 
Tab. 2. Relative expression of OIP5-AS1 in lung cancer samples compared with ANCTs in age- and sex-based subgroups of patients (HDI - 95\% credible interval based on Bayesian approach).

\begin{tabular}{|c|c|c|c|c|c|c|c|}
\hline \multicolumn{2}{|c|}{ OIPS-AS expression } & Sample number & Relative expression & SD & Effect size & $\mathbf{p}$ & 95\% HDI \\
\hline \multicolumn{2}{|l|}{ total } & 32 & -2.815 & 0.73 & -0.721 & $<0.0001$ & $-4.28,-1.37$ \\
\hline \multicolumn{2}{|l|}{ male } & 24 & -2.976 & 0.9191 & -0.718 & 0.016 & $-4.75,-1.11$ \\
\hline \multicolumn{2}{|c|}{ female } & 8 & -2.385 & 1.6 & -0.667 & 0.101 & $-5.52,0.78$ \\
\hline \multirow[t]{2}{*}{$<60$} & male & 15 & -4.201 & 1.462 & -0.947 & 0.006 & $-7.06,-1.24$ \\
\hline & female & 5 & -1.668 & 5.15 & -0.385 & 0.406 & $-10.15,7.24$ \\
\hline \multirow[t]{2}{*}{$\geq 60$} & male & 9 & -1.774 & 1.288 & -0.456 & 0.12 & $-4.35,0.75$ \\
\hline & female & 3 & -2.975 & 5.533 & -0.703 & 0.223 & $-11.89,6.55$ \\
\hline
\end{tabular}

ANCT - adjacent non-cancerous tissue, HDI - human development index, SD - stadard deviation

\section{Association study of}

OIP5-AS1 expression and

clinicopathological data of patients No association was found between relative expression of OIP5-AS1 and clinicopathological data of patients (Tab. 3).

\section{Assessment of correlation between OIP5-AS1 expression and patient's age}

There was no correlation between patient's age and relative expression of OIP5-AS1 either in tumor tissues or in ANCTs (Graph 1).

\section{Discussion}

The critical roles of IncRNAs in regulation of genes involved in DNA repair [14], induction of epithelial to mesenchymal transition (EMT) $[15,16]$, inhibition of tumor suppressors $[17,18]$, control of apoptosis and cellular metabolism [19] and regulation of nuclear receptors function [20] potentiate them as molecular markers of cancer. Expression levels of several IncRNAs have been assessed in lung cancer specimens and cell lines. For instance, the metastasis-associated lung adenocarcinoma transcript 1 (MALAT1) has been recognized as a predictive marker of metastatic capacity of lung cancer cells which acts through modulation of expression of several metastasis-associated genes [21]. The maternally expressed gene 3 (MEG3) has also been involved in the EMT in lung cancer cells [22]. The oncogenic effects of OIP5-AS1 have also been clarified in

Tab. 3. Association study of OIP5-AS1 expression and clinicopathological data of patients.

$\begin{array}{cccc}\text { OIP5-AS1 } & \text { OIP5-AS1 } & \text { Total } & p \\ \text { up-regulation down-regulation } & \text { number }\end{array}$

Age

\begin{tabular}{|l|c|c|c|}
\hline$<60$ years & $7(43.8 \%)$ & $9(56.3 \%)$ & 16 \\
\hline 260 years & $8(50 \%)$ & $8(50 \%)$ & 16 \\
\hline
\end{tabular}

\section{Gender}

\begin{tabular}{|l|c|c|c|c|}
\hline male & $12(50 \%)$ & $12(50 \%)$ & 24 & 0.691 \\
\hline female & $3(37.5 \%)$ & $5(62.5 \%)$ & 8 & \\
\hline
\end{tabular}

\section{Smoking}

\begin{tabular}{|l|c|c|c|c|}
\hline yes & $12(48 \%)$ & $13(52 \%)$ & 25 & 1 \\
\hline no & $3(42.9 \%)$ & $4(57.1 \%)$ & 7 & \\
\hline
\end{tabular}

\section{Stage}

\begin{tabular}{|l|l|l|l|l}
\hline I & $6(85.7 \%)$ & $1(14.3 \%)$ & 7 & 0.068 \\
\hline II & $3(27.3 \%)$ & $8(72.7 \%)$ & 11 & \\
III & $6(42.9 \%)$ & $8(57.1 \%)$ & 14 &
\end{tabular}

\section{Subtype}

\begin{tabular}{|l|l|l|l|l|}
\hline adenocarcinoma & $7(38.9 \%)$ & $11(61.1 \%)$ & 18 & 0.305 \\
\hline squamous cell carcinoma & $8(57.1 \%)$ & $6(42.9 \%)$ & 14 &
\end{tabular}

lung adenocarcinoma recently [13]. This IncRNA is transcribed in the antisense direction from the OIP5 gene, an oncogene overexpressed in numerous malignancies [23]. While OIP5-AS1 plays oncogenic roles in lung cancer [13], in HeLa cells, it inhibits cell proliferation possibly through interaction with the RNA-binding protein of human antigen (RBP HuR) and decreasing its readiness to target mRNAs of cyclins $A$ and D1 (CCNA2 and CCND1) and SIRT1 [24]. In an effort to validate the results of the previous study on the role of OIP5-AS1 


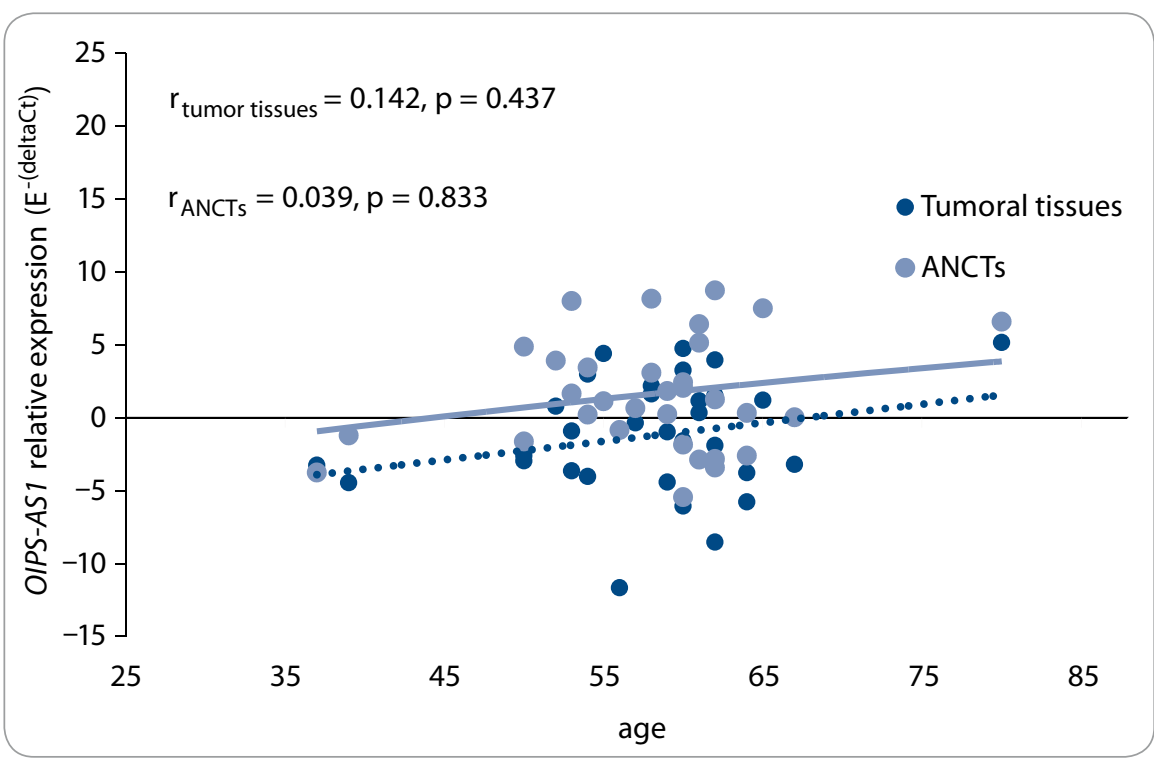

Graph. 1. Correlation between patient's age and OIPS-AS1 relative expression in tumoral tissues as well as ANCTs ( $\mathrm{E}$ - efficiency, delta $\mathrm{Ct}=\mathrm{Ct}_{\text {OIP5-AS }}-\mathrm{Ct}_{\text {HPRT }}$ ).

ANCT - adjacent non-cancerous tissue

in lung cancer [13] and assess its potential as a biomarker in these patients, we evaluated the expression levels of this IncRNA in NSCLC samples from Iranian patients compared with the corresponding ANCTs. However, contrary to Deng et al. we detected down-regulation of its expression levels in tumor tissues compared with ANCTs. Nevertheless, our study is in line with Deng et al., study regarding the lack of association between OIP5-AS1 expression levels and patient's age. We also assessed the association between its expression levels and history of smoking in patients as well as disease stage and found no associations. The latter parameters were not evaluated in Deng et al. study. The discrepancy between the results of our current study and those of Deng et al. [13] can be explained by the heterogeneity of samples in our study (comprising both adenocarcinoma and squamous cell carcinoma) or the inherent difference in the pathogenesis of lung cancer due to geographic-related dissimilarities or hazards exposures. A previous study revealed geography-related patterns in the methylation profiles of NSCLC tumors [25]. Moreover, exposure to inorganic dusts, heavy metals and chemical compounds has been associated with lung cancer risk in Iranian patients [26]. Thus, the possibility of specific geographic-based hazards and their possible effects on gene expression signature cannot be ignored. Consequently, population-based studies are needed to explore the role of IncRNAs in the pathogenesis of cancers in each region to design appropriate targeted therapies for each population.

\section{References}

1. Didkowska J, Wojciechowska U, Manczuk M et al. Lung cancer epidemiology: contemporary and future challenges worldwide. Ann Transl Med 2016; 4(8): 150. doi: 10.21037/atm.2016.03.11

2. Vardanjani HM, Zeinali M, Radmerikhi S et al. Lung cancer prevalence in Iran by histologic subtypes. Adv Biomed Res 2017; 6: 111. doi: 10.4103/2277-9175.213881.

3. Zappa C, Mousa SA. Non-small cell lung cancer: curren treatment and future advances. Trans Lung Cancer Res 2016; 5(3): 288-300. doi: 10.21037/tlcr.2016.06.07.

4. Zhou CC, Wu YL, Chen GY et al. Erlotinib versus che motherapy as first-line treatment for patients with advanced EGFR mutation-positive non-small-cell lung cance (OPTIMAL, CTONG-0802): a multicentre, open-label, randomised, phase 3 study. Lancet Oncol 2011; 12(8): 735 742. doi: 10.1016/S1470-2045(11)70184-X.

5. Pathy S, Roy S, Malik PS et al. Treatment compliance and outcome in geriatric patients with locally advanced non-small cell lung cancer: experience from India. Iranian Journal of Cancer Prevention 2016; 9(6): e5481. doi 10.17795/ijcp-5481 sion analysis of AFAP1-AS1 and AFAP1 in breast cancer. Cancer Biomark 2018; 22(1): 49-54. doi: 10.3233/CBM170831.

7. Taheri M, Omrani MD, Ghafouri-Fard S. Long non-COding RNA expression in bladder cancer. Biophys Rew 2017. doi: 10.1007/s12551-017-0379-y.

8. Taheri M, Pouresmaeili F, Omrani MD et al. Association of ANRIL gene polymorphisms with prostate cancer and be-
6. Dianatpour A, Faramarzi S, Geranpayeh $L$ et al. Expres- nign prostatic hyperplasia in an Iranian population. Biomar Med 2017; 11(5): 413-422. doi: 10.2217/bmm-2016-0378.

9. Nikpayam E, Tasharrofi B, Sarrafzadeh S et al The role of long non-coding RNAs in ovarian cancer. Iran Biomed J 2017; 21(1): 3-15. doi: 10.6091/.21.1.24.

10. Soudyab M, Iranpour M, Ghafouri-Fard S. The role of long non-coding RNAs in breast cancer. Arch Iran Med 2016; 19(7): 508-517. doi: 0161907/AIM.0011.

11. Taheri M, Omrani MD, Ghafouri-Fard S. Long non-coding RNAs expression in renal cell carcinoma. Journal of Biology and Today's World 2017; 6(12): 240-247. doi: 10.15412/J.JBTW.01061201.

12. Xu G, Chen J, Pan QS et al. Long non-coding RNA expression profiles of lung adenocarcinoma ascertained by microarray analysis. PLoS One 2014; 9(8): e104044. doi: 10.1371/journal.pone.0104044.

13. Deng J, Deng H, Liu C et al. Long non-coding RNA OIP5-AS1 functions as an oncogene in lung adenocarcinoma through targeting miR-448/BCl-2. Biomed Pharmacother 2018; 98: 102-110. doi: 10.1016/j.biopha.2017.12.031.

14. Dianatpour A, Ghafouri-Fard S. The role of long non coding RNAs in the repair of DNA double strand breaks. Int J Mol Cell Med 2017; 6(1): 1-12.

15. Dianatpour A, Ghafouri-Fard S. Long non coding RNA expression intersecting cancer and spermatogenesis: a systematic review. Asian Pac J Cancer Prev 2017; 18(10): 2601-2610. doi: 10.22034/APJCP.2017.18.10.2601.

16. Nikpayam E, Soudyab M, Tasharrofi B et al. Expression analysis of long non-coding ATB and its putative target in breast cancer. Breast Dis 2017; 37(1): 11-20. doi: 10.3233/BD-160264.

17. Khorshidi HR, Taheri M, Noroozi R et al. ANRIL genetic variants in iranian breast cancer patients. Cell J 2017; 19 (Suppl 1): 72-78. doi: 10.22074/cellj.2017.4496.

18. Iranpour M, Soudyab M, Geranpayeh L et al. Expression analysis of four long noncoding RNAs in breast cancer. Tumour Biol 2016; 37(3): 2933-2940. doi: 10.1007/s13277-015-4135-2.

19. Taheri M, Habibi M, Noroozi R et al. HOTAIR genetic variants are associated with prostate cancer and benign prostate hyperplasia in an Iranian population. Gene 2017; 613: 20-24. doi: 10.1016/j.gene.2017.02.031.

20. Faramarzi S, Dianatpour A, Ghafouri-Fard S. Discovering the role of long non-coding RNAs in regulation of steroid receptors signaling in cancer. Journal of Biology and Today's World 2017; 6(12): 248-258. doi: 10.15412/J. JBTW.01061202.

21. Gutschner T, Hammerle M, Eissmann M et al. The noncoding RNA MALAT1 is a critical regulator of the metastasis phenotype of lung cancer cells. Cancer research 2013; 73(3): 1180-1189. doi: 10.1158/0008-5472.CAN-12-2850. 22. Terashima M, Tange S, Ishimura A et al. MEG3 long noncoding RNA contributes to the epigenetic regulation of epithelial-mesenchymal transition in lung cancer cell lines. J Biol Chem 2017; 292(1): 82-99. doi: 10.1074/jbc. M116.750950

23. Kim J, Noh JH, Lee SK et al. LncRNA OIP5-AS1/cyrano suppresses GAK expression to control mitosis. Oncotarget 2017; 8(30): 49409-49420. doi: 10.18632/oncotarget.17219.

24. Kim J, Abdelmohsen K, Yang XL et al. LncRNA OIP5-AS1/cyrano sponges RNA-binding protein HuR. Nucleic Acids Res 2016; 44(5): 2378-2392. doi: 10.1093/nar/ gkw017

25. Toyooka S, Maruyama R, Toyooka KO et al. Smoke exposure, histologic type and geography-related differences in the methylation profiles of non-small cell lung cancer. Int J Cancer 2003; 103(2): 153-160. doi: 10.1002/ijc.10787

26. Hosseini M, Naghan PA, Karimi S et al. Environmental risk factors for lung cancer in Iran: a case-control study. Int J Epidemiol 2009; 38(4): 989-996. doi: 10.1093/ije/dyp218. 